\title{
A Trematode Larva from Buccinum undatum and Notes on Trematodes from Post-Larval Fish.
}

\author{
By Marie V. Lebour, D.Sc. \\ Naturalist at the Plymouth Laboratory.
}

With Figures 1 to 7 at the end.

ON May 30th, 1916, a number of large Buccinum undatum were brought in from the trawling grounds; 40 of these were examined and 34 were found to contain larval Trematodes. Another lot in the spring of 1917 contained about the same percentage of infected Mollusks. Two species of Trematodes were present, both contained in the digestive gland, which was absolutely riddled with them.

The first, which was in 4 out of 40 Buccinum, was identified as Cercaria neptuni Lebour (1912), previously found in both Neptunea antiqua and Buccinum undatum from the Northumberland coast. This is a thicktailed cercaria contained in long colourless rediæ which are tightly packed in the digestive gland and give to this organ a characteristic sickly grey appearance quite unlike its ordinary healthy state, so that infected specimens can easily be recognized by cutting a small aperture in the spire of the shell and examining the portion of digestive gland exposed. The further life history of this cercaria is unknown.

The second species occurs much more commonly and was found in 30 out of 40 Buccinum examined. The colour of the infected digestive gland is this time an unhealthy pinkish yellow, which is characteristic. The cercariæ are contained in sporocysts which occupy almost the whole of the spire of the shell.

The anatomy of this cercaria shows it to be almost certainly a larval stage of Zoogonus viviparus (Olsson), the life history of which is so far unknown (Odhner, 1902). This Trematode in the adult state lives in the intestine of many common fish. It has been recorded from 11 different. species, 9 of which are from the Channel-Zeus faber, Blennius gattorugine, Blennius ocellaris, Solea vulgaris, Solea variegata, Pleuronectes limanda, Pleuronectes microcephalus, Pleuronectes platessa and Callionymus lyra. Nicoll (1914) regards Callionymus lyra, Pleuronectes spp. and Solea spp. as undoubtedly their chief hosts, all of these being common on the trawling grounds where the Buccinum were caught. 
An intermediate host has not yet been identified, but from the structure of the cercaria, which is able to modify the posterior end of its body as a sucker-like organ, it is probable that the intermediate host is an actively swimming animal, as in all probability the sucker is used by the cercaria for fixing the hind end of its body whilst the free part waves about in order to catch a host. The stylet on the head and its glands opening beside it show that the cercaria bores into its host.

\section{STRUCTURE OF SPOROCYST AND CERCARIA.}

The sporocyst is faintly yellow in colour and measures from 0.5 to $1 \mathrm{~mm}$. in length and is from 2 to 4 times as long as it is broad. Inside the sporocyst are germ cells and cercariæ in various stages, from 1 to 8 in each sporocyst (Fig. 1).

The full grown cercaria is colourless and transparent, measuring $0.33 \mathrm{~mm}$. to $0.48 \mathrm{~mm}$. in length according to the extent of contraction or expansion (Figs. 2 and 3). The anterior end is rather more rounded than the posterior end and usually the greatest width is in front of the oral sucker, although when the body is greatly extended the width is nearly equal for the whole length, a great amount of extension being possible. The oral sucker is a little more than half the width of the ventral sucker. Oral sucker $0.06 \mathrm{~mm}$., ventral sucker $0.10 \mathrm{~mm}$. Both are well developed and conspicuous. The whole surface of the body is covered with minute spines which enlarge towards the posterior end and are greatly elongated round that portion which is capable of forming the round disc in the middle of which opens the excretory bladder. The posterior end can, however, change its shape so that the dise is not always present (Fig. 6).

The oral sucker bears at its anterior end dorsally a thick stylet, $0 \cdot 015$ mm. long, with a long central and two small lateral points. On each side of the spine opening dorsally are situated a pair of long curved ducts (Fig. 5) connected with a mass of large gland cells on each side, the stylet glands, which occupy the space between the oral and the ventral sucker. The oral sucker has a large circular aperture ventrally placed near the anterior end of the body which leads to a short pre-pharynx, which in the expanded state may be as long as the pharynx but is usually much shorter. Then follows a conspicuous muscular pharynx, $0.03 \mathrm{~mm}$. long, a thin-walled œsophagus and short intestinal diverticula reaching to about the centre of the ventral sucker. In transverse section the tubes of the diverticula are seen to be composed of very few cells, sometimes only two, with large nuclei (Fig. 7).

The ventral sucker is large and muscular with a somewhat oval centre. Immediately behind it and to the sides are the testes, which are well 
developed compact oval masses of cells with large nuclei. Ovary and vitellaria are not as yet differentiated, although masses of nuclei probably represent these in the process of formation.

The excretory vesicle is an oblong sac with very thick walls composed of large cells. It is conspicuous at the hind end of the body reaching to about the level of the posterior margin of the testes and opening at the extreme hind end in a small papilla.

These features show it to be very like the structure of Zoogonus viviparus (see Lebour, 1908), allowing for growth and development especially of the region behind the ventral sucker and of the reproductive organs. The fact also that it is the only really common fish Trematode of these parts with such short intestinal diverticula supports the view. The relationship of this cercaria to the stumpy-tailed forms seems obvious, the stumpy tail in this case being replaced by the peculiar sucker-like disc. The thick-walled excretory vesicle is common to this species and to all in the group and also the boring spine and glands. Except for the peculiarly modified hind end it fits very well into Dollfus' group (1914) of Cotylocercous cercariæ, which are all developed in sporocysts in marine gastropods. None of their life histories are so far known.

I have to thank my colleague, Miss G. E. Webb, for making the sections which were used in working out the structure of the cercaria in order to determine points not easily seen in the living material.

\section{TREMATODES IN POST-LARVAL FISH.}

Whilst investigating the food of young fish a number of Trematodes were found. Some of these were immature, others adult and containing ova. Those most frequently found were Derogenes varicus and Pharyngora bacillaris. Derogenes varicus is a common parasite of many fish, notably the Pleuronectids, and in an immature state was found in several fish, particularly Arnoglossus and Scophthalmus norvegicus. The only intermediate hosts so far known for this species are Sagitta and Harmothoë, so it is somewhat difficult to say how the worm enters the small fish as they almost certainly do not eat these worms. The most likely explanation seems to be that by the death of the worm host the young Trematode is set free and is then swallowed along with other food by tiny fish in which it afterwards matures.

Derogenes varicus was found in the following fish:-

$\begin{array}{lrll}\text { Arnoglossus } \text { sp. } & 23 & \text { Solea variegata } & 4 \\ \text { Scophthalmus norvegicus } & 18 & \text { Gadus minutus } & 2 \\ \text { Pleuronectes limanda } & 11 & \text { Gadus merlangus } & 1 \\ \text { Pleuronectes microcephalus } & 4 & \text { Callionymus lyra } & 1\end{array}$


Pharyngora bacillaris, which inhabits the Mackerel and a few other fish in the adult state, when immature is found abundantly in the townettings both free and in Medusæ, Ctenophores and Sagitta. It is the only common Trematode of the plankton and might easily be swallowed by small fish. It occurred in a few sprats, in 3 Onos mustela and in one Rhombus lavis.

Podocotyle atomon, another common fish Trematode, occurred in 3 specimens of Gasterosteus spinachia, and in all cases contained ova.

An encysted Trematode occurred in the peritoneum of 2 specimens of Syngnathus rostellatus.

The Horse Mackerel, Caranx trachurus, on one occasion contained a mature Trematode, probably Lecithaster sp.

\section{LITERATURE.}

1914. Dollfus, $R$. "Cercaria pachycerca Diesing, et les cercaires à queue dite en mignon." IX Congrès Int. de Zool. Monaco.

1908. Lebour, M. V. "Fish Trematodes of the Northumberland Coast." North Sea Fish. Rep. for 1907.

1912. -. "A Revision of the Marine Cercariæ." Parasitology, No. 4.

1914. Nicoll, $W$. "The Trematode Parasites of Fishes from the English Channel." Journ. Mar. Biol. Assoc., N.S., X., No. 4. 


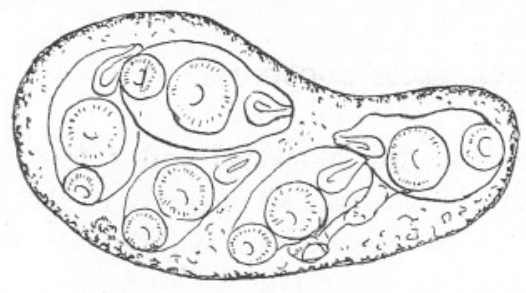

1.

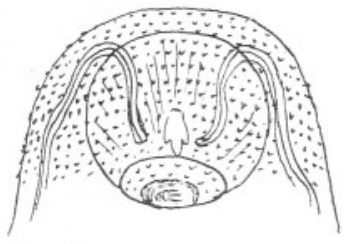

5.
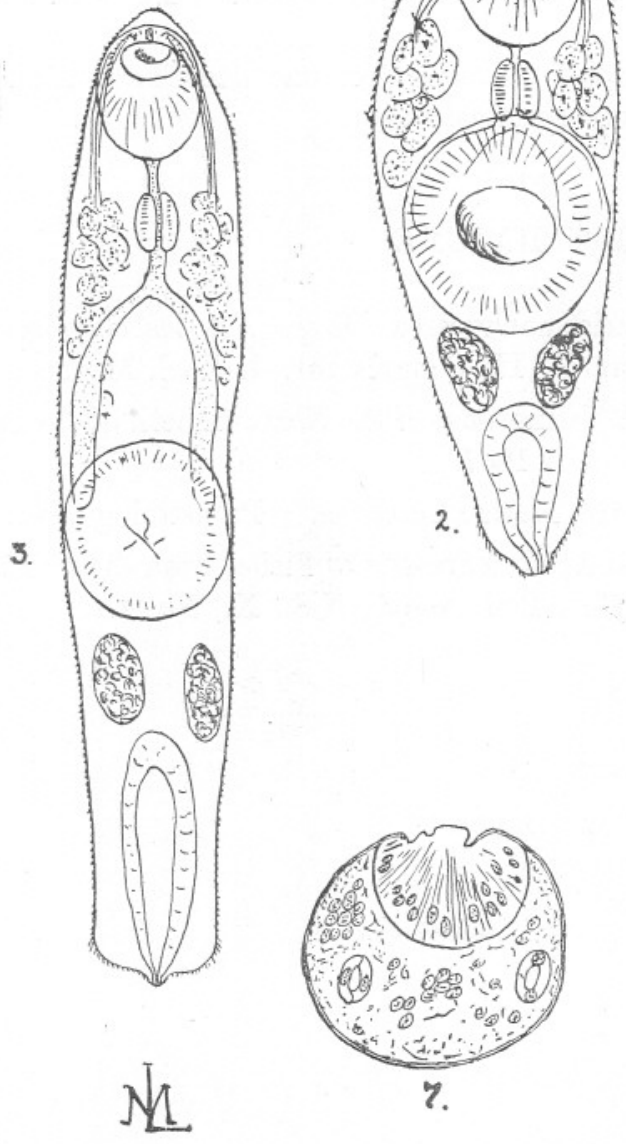

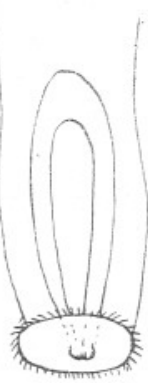

6.

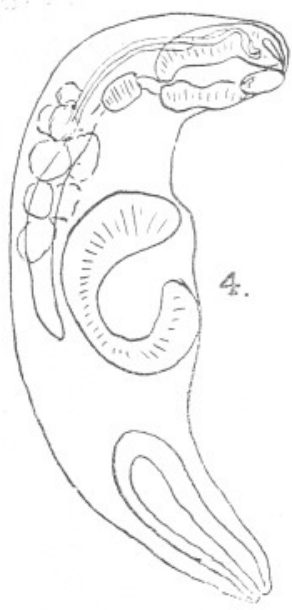

CERCARIA NEPTUNI Lelour.

\section{EXPLANATION OF FIGURES.}

FIG، 1. Sporocyst containing cercariæ from the digestive gland of Buccinum undarum.

2. Cercaria somewhat contracted.

3 Cercaria expanded.

4. Side view of cercaria.

5. Head of cercaria bent forward to show stylet and glands.

6. Spiny disc at posterior end of cercaria.

7. Transverse section of cercaria through the ventral sucker and intestinai diverticula. 